\title{
Diurnal and Seasonal Courses of Photosynthesis, Transpiration and Water Use Efficiency of Japanese Cypress and Japanese Red Pine Seedlings in Different Soil Water Conditions
}

\author{
HAN, Qingmin, KAKUBARI, Yoshitaka \\ 異なる土壤水分条件下で育てたヒノキとアカマツ苗木の \\ 光合成・蒸散・水利用効率の日変化及び季節変化 \\ 韓 慶民・角張嘉孝 \\ Summary
}

\begin{abstract}
Net photosynthesis and transpiration of 3-year old seedlings of Japanese cypress (Chamaecyparis obtusa Endl.) and Japanese red pine (Pinus densiflora Sieb. et Zucc.) were measured as diurnal courses and seasonal fluctuation from May to November in 1994. Three levels of soil moisture were achieved by controlling the irrigated amount of water. Net photosynthesis of both species peaked in the morning, transpiration reached its peak later than net photosynthesis. Net photosynthesis and transpiration decreased in lower water conditions as well as stomatal conductance. However, no distinct differences in water use efficiency was observed among all three treatments. Integrated daily $\mathrm{CO}_{2}$ uptake peaked in July, for Japanese cypress ; and in August, for Japanese red pine. Integrated daily $\mathrm{H}_{2} \mathrm{O}$ release had similar patterns to integrated daily $\mathrm{CO}_{2}$ uptake in most treatments except $\mathrm{pF} 2.7$ of Japanese red pine, whereas it peaked in October. Daily water use efficiency was higher in early summer and late autumn than in mid summer, for Japanese cypress; but was relatively steady, for Japanese red pine. Integrated daily $\mathrm{CO}_{2}$ uptake and $\mathrm{H}_{2} \mathrm{O}$ release of both species decreased in lower water conditions. However, there was no significant difference among all three treatments in daily water use efficiency. Net photosynthesis of Japanese red pine was higher than that of Japanese cypress under the same water stress conditions. Japanese red pine is more drought-tolerant than Japanese cypress.
\end{abstract}

Key words : Japanese cypress, Japanese red pine, photosynthesis, stomatal conductance, water use efficiency, water stress

キーワード：ヒノキ, アカマツ, 光合成, 気孔コンダクタンス, 水利用効率, 水ストレス

Fac. of Agric., Univ. of Shizuoka, Ohya 836, Shizuoka 422, Japan

静岡大学農学部 静岡市大谷 836 


\section{Introduction}

The effect of soil water status on photosynthesis or transpiration of Japanese cypress and Japanese red pine, which are the main two forest tree species in Japan, has been well studied separately. SATOo (1956) reported qualitatively that Japanese red pine is more drought-tolerant than Japanese cypress by measuring transpiration of detached twigs. NEGISI (1966) came to the conclusion that photosynthesis of Japanese red pine responds more sensitively to soil water than that of Japanese cypress. The critical soil moisture at which the transpiration of a Japanese cypress stand began to decline had been estimated at pF 2.45 using the micrometeorological approach (HATTORI et al., 1993).

The gas exchange of carbon dioxide $\left(\mathrm{CO}_{2}\right)$ and water vapor between plants and the atmosphere passes through the same stomata (LARCHER, 1965). Regulation of gas exchange is important for plant performance, to maintain growth without desiccation in the atmosphere (ScHULzE, 1986). In recent years, it has been possible to measure the gas exchange of carbon dioxide and water vapor at the same time, and extensive studies on the effect of stomatal conductance on gas exchange have been completed (FARQUHAR and Sharkey, 1982; Schulze, 1986). The comparative studies on the effect of soil water status on photosynthesis and transpiration between Japanese cypress and Japanese red pine is still lacking. The stomatal regulation effect on gas exchange of these two species is not fully understood yet.

Studying diurnal patterns of water relations, photosynthesis and related parameters can provide fundamental information on plant responses and adaptations to natural environments (SCHULzE and HALL, 1982). In this paper, we examined the effect of soil water status on the 3-year old seedlings of Japanese cypress and Japanese red pine under three levels of soil moisture. Our specific objectives were to : 1) measure diurnal and seasonal courses of gas exchange and stomatal conductance under three steady soil water conditions ; 2) find the relationship between stomatal conductance and gas exchange ; 3) try to find the optimum soil water conditions for these species.

\section{Materials and Methods}

\subsection{Materials}

Three year old seedlings of Japanese cypress (Chamaecyparis obtusa Endl.) and Japanese red pine (Pinus densiflora Sieb. et Zucc.) were transplanted from a nursery to pots, and have been growing in greenhouse conditions since February, 1994. The general characteristics of the materials are shown in Table 1. Pots were watered according to the following methods and fertilized every 2 weeks with Hyponex solution ( $\mathrm{N}: \mathrm{P}: \mathrm{K}=5: 10: 5)$ during the growing season.

2.2 Soil moisture control

The soil in each pot was Kanuma tsuchi (volcanic soil). Seedlings were planted in Wagner pots (1/ 2000a) with the equal amount of air-dried Kanuma tsuchi.

The $\mathrm{pF}$-soil moisture curve (Fig. 1) was measured using the centrifuging method to control soil moisture levels.

The resistance to an extreme depression in soil moisture content is considered to be intermediate, for

Table 1 General characteristics of sample seedlings

\begin{tabular}{ccccc}
\hline \multicolumn{1}{c}{ Species } & Treatment & $\begin{array}{c}\text { Height } \\
(\mathrm{cm})\end{array}$ & $\begin{array}{c}\text { Diameter at } \\
\text { ground surface }(\mathrm{cm})\end{array}$ & $\begin{array}{c}\text { Top and root } \\
\text { fresh weight }(\mathrm{g})\end{array}$ \\
\hline Japanese cypress & $\mathrm{pF} 2.2$ & 80.4 & 0.71 & 107.2 \\
Japanese cypress & $\mathrm{pF} 2.7$ & 79.8 & 0.95 & 134.1 \\
Japanese cypress & $\mathrm{pF} 3.2$ & 82.8 & 0.75 & 128.0 \\
Japanese red pine & $\mathrm{pF} 2.7$ & 72.8 & 1.09 & 68.9 \\
Japanese red pine & $\mathrm{pF} 3.2$ & 70.0 & 0.98 & 62.0 \\
Japanese red pine & $\mathrm{pF} 4.0$ & 64.8 & 0.87 & 62.6 \\
\hline
\end{tabular}




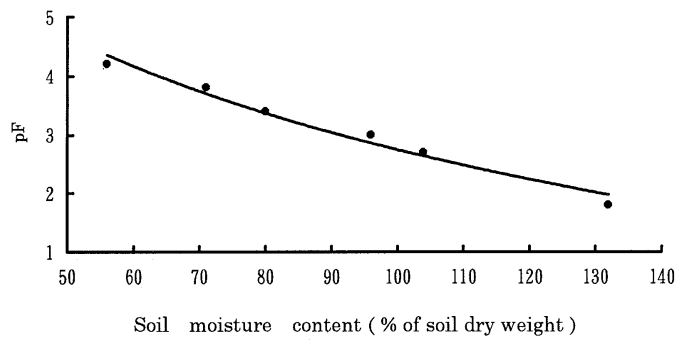

Fig. 1 pF-soil moisture curve.

Japanese cypress, high for Japanese red pine in comparison with Japanese cedar (Cryptomeria japonica D. Don), which is considered to be low (NEGISI, 1966). We set the soil moisture on three levels about $\mathrm{pF}$ $2.2(-0.02 \mathrm{MPa}, 118 \%$ moisture content expressed as percentage of soil dry weight), $\mathrm{pF} 2.7(-0.05 \mathrm{MPa}$, $99 \%$ ), and $\mathrm{pF} 3.2$ (-0.16 $\mathrm{MPa}, 82 \%)$, for Japanese cypress ; $\mathrm{pF} 2.7, \mathrm{pF} 3.2$, and $\mathrm{pF} 4.0(-0.98 \mathrm{MPa}, 63 \%)$, for Japanese red pine.

In each treatment, one heat probe sensor (IDL-1600, North Hightech Co. LTD.) was set to measure the soil moisture every 30 minutes. We collected the soil moisture content every day from the data logger and calculated the water loss amount caused by evapotranspiration, and then watered the pot to keep the soil moisture at the required levels.

2.3 Physiological measurement

Diurnal changes of net photosynthesis rate $\left(\mathrm{Ph}_{\mathrm{n}}\right)$ and transpiration rate $(\mathrm{Tr})$ were measured using the same newly sprouted leaves from May to November, between 0600 and 1800 at 1 hour intervals. As needles of Japanese red pine were still sprouting in May and June, measurements were started from July. Measurements were made on a clear day using simultaneously operated porometer systems (CQP-130, Walz Co.) (SchUlzE et al., 1982; LANGE et al., 1984). The porometer system also recorded PAR (photosynthetically active radiation), air and leaf temperature, ambient relative humidity, ALVPD (air to leaf vapor pressure deficit), stomatal conductance to $\mathrm{CO}_{2}$ and $\mathrm{H}_{2} \mathrm{O}$, and intercellular $\mathrm{CO}_{2}$ concentration.

The measured leaves of Japanese red pine were detached and leaf areas were measured using the Delta -T Image Analysis System (DIAS, DELTA-T DEVICES LTD.) after measuring in November. DIAS uses a PC computer to analyze video images. The leaf images were recorded by the computer using a video camera (JVC TK-S310U). DIAS can measure length and width also. In the case of Japanese cypress, leaf areas were measured by recording the leaf images directly using the above method every month after the measurement of diurnal changes.

From the diurnal curves of $\mathrm{Ph}_{\mathrm{n}}$ and $\mathrm{Tr}$, the diurnal curves of water use efficiency (WUE) were estimated. In addition, daily $\mathrm{CO}_{2}$ uptake (IDCU) and $\mathrm{H}_{2} \mathrm{O}$ release (IDHR) were estimated per unit leaf area by measuring the area beneath diurnal curves of $\mathrm{Ph}_{n}$ and $\mathrm{Tr}$ respectively (WAYNE and BAZZAZ, 1993). The seasonal fluctuation of $\mathrm{Ph}_{\mathrm{n}}$, $\mathrm{Tr}$ and WUE were estimated by using the integrated IDCU, IDHR and IDCU/IDHR ratios during each month, respectively.

\section{Results}

\subsection{Soil water control}

Soil water conditions are illustrated in Fig. 2. The points showing a dramatic increase are the times at which irrigation took place. This figure shows only five days' data in the middle of August while the soil moisture of each treatment was kept at steady levels respectively during this study. Soil moisture contents have been measured by oven-drying method to verify whether or not heat probe sensor can measure and control soil moisture correctly. The results are shown in Fig. 3. From the strong coefficient of determination of 0.92 , it can be considered that the heat probe sensor can efficiently control soil water. 


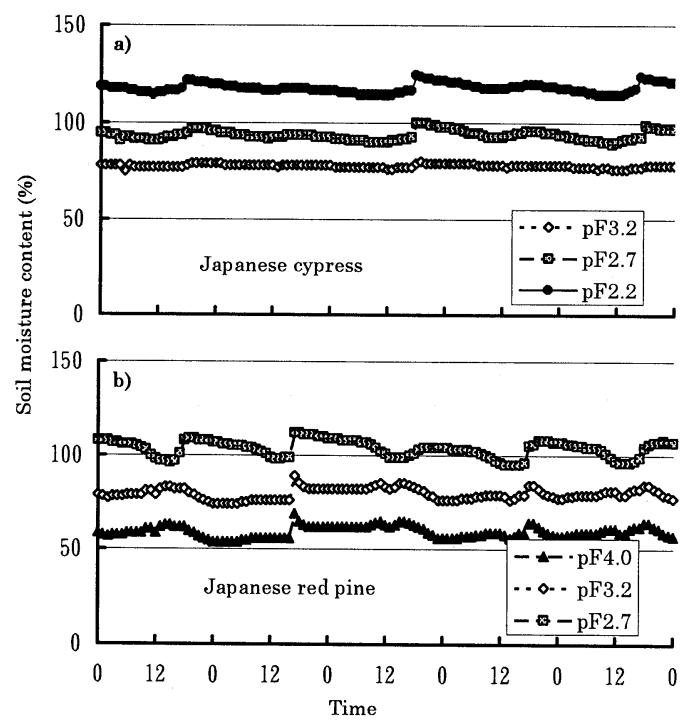

Fig. 2 Soil water conditions of Japanese cypress (Chamaecyparis obtusa Endl.) and Japanese red pine (Pinus densiflora Sieb. et Zucc.) from 10 Aug. to 14 Aug. 1994.

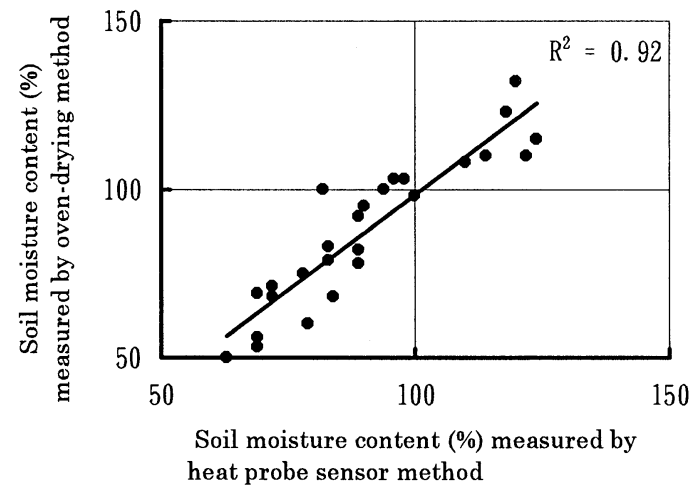

Fig. 3 A comparison of heat probe sensor method to oven-drying method in measurement of soil moisture content.

3.2 Diurnal courses of photosynthesis, transpiration, water use efficiency and stomatal conductance The diurnal courses of $\mathrm{Ph}_{n}$, Tr and WUE for Japanese cypress and Japanese red pine are illustrated in Fig. 4 from May to November, and in Fig. 5 from July to November, respectively.

$\mathrm{Ph}_{\mathrm{n}}$ of Japanese cypress and Japanese red pine peaked in the morning in most measurements. Midday depression of $\mathrm{Ph}_{\mathrm{n}}$ was observed in both species in most measurements. Both species showed decreases of $\mathrm{Ph}_{\mathrm{n}}$ in lower soil water potential treatments compared with that in higher soil water potential treatments. Tr of both species reached its peak later than $\mathrm{Ph}_{n}$ in most measurements. $\mathrm{Tr}$ decreased in lower soil water potential treatments.

As shown in Table 2, the maximum daily $\mathrm{Ph}_{\mathrm{n}}$ and $\mathrm{Tr}$ of Japanese cypress changed to $83 \% \sim 93 \%$ and $62 \% \sim 102 \%$ in $\mathrm{pF} 2.7,55 \% \sim 94 \%$ and $38 \% \sim 76 \%$ in $\mathrm{pF} 3.2$, respectively, in comparison to levels in $\mathrm{pF} 2.2$. On the other hand, Japanese red pine changed $\mathrm{Ph}_{\mathrm{n}}$ and $\mathrm{Tr}$ to $71 \% \sim 94 \%$ and $72 \% \sim 109 \%$ in $\mathrm{pF} 3.2,70 \%$ 

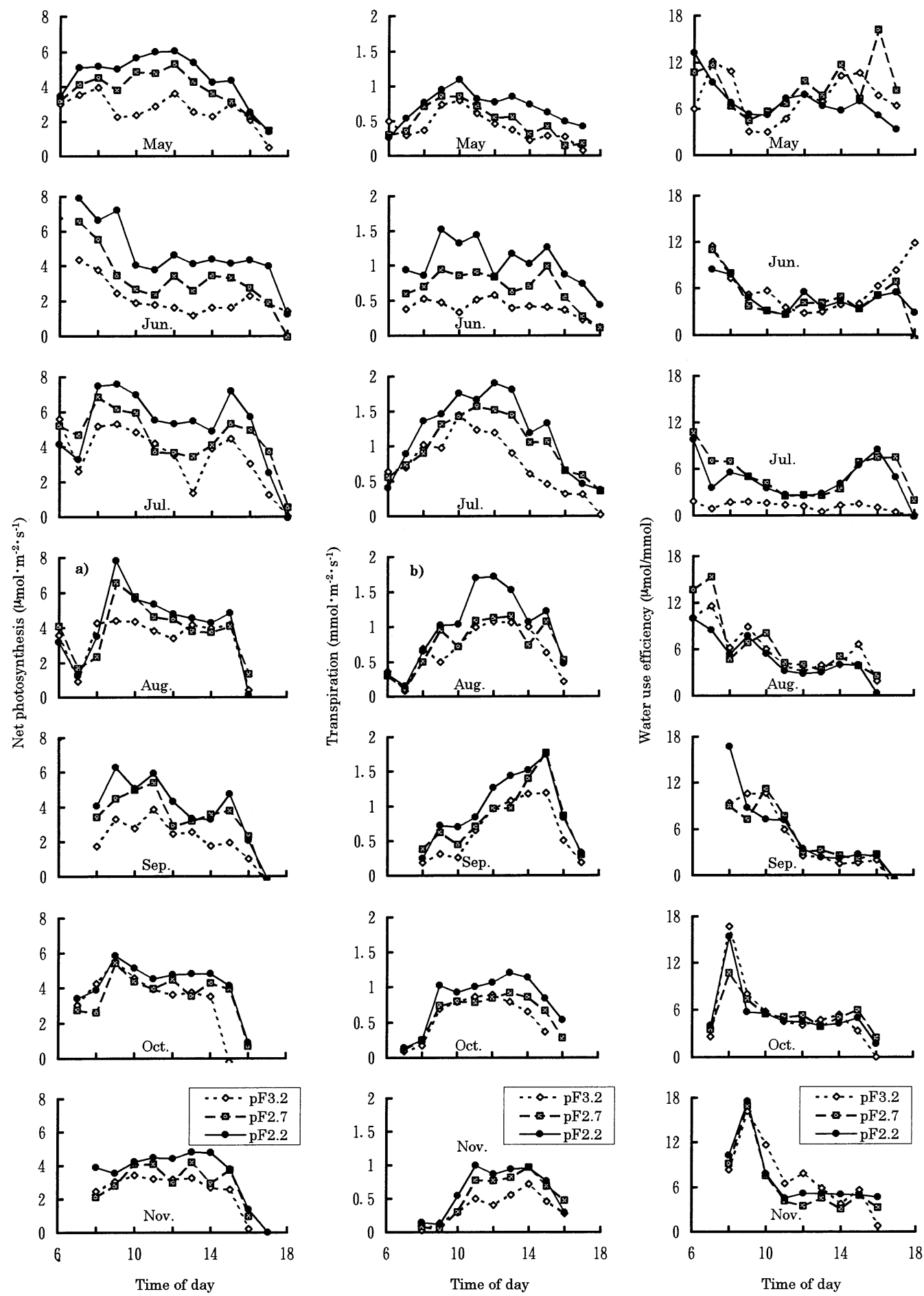

Fig. 4 The diurnal courses of net photosynthesis, transpiration and water use efficiency for Japanese cypress (Chamaecyparis obtusa Endl.). a) and b) marks will be used in 4.1 Increasing water deficits and leaf gas exchange. 

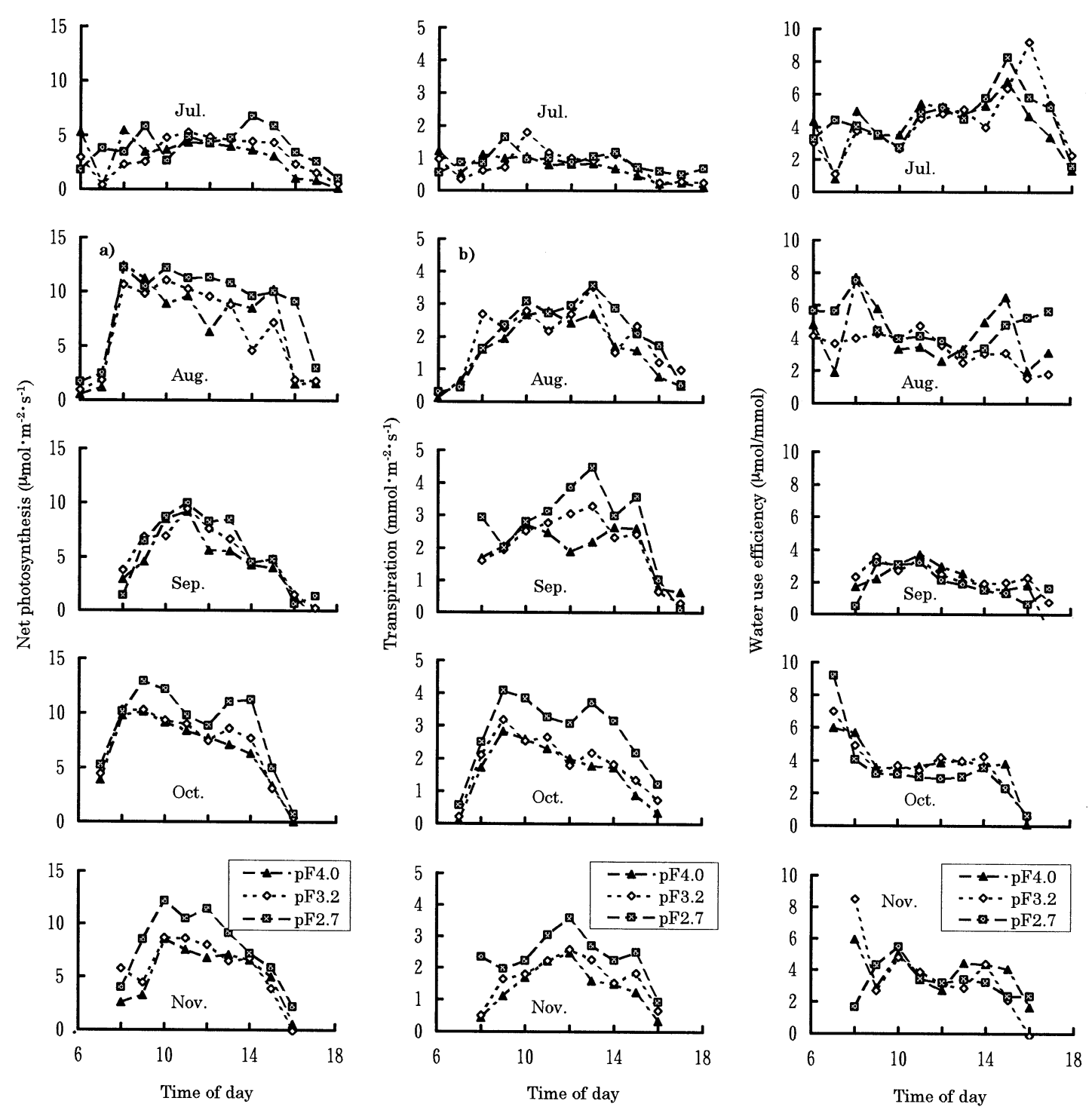

Fig. 5 The diurnal courses of net photosynthesis, transpiration and water use efficiency for Japanese red pine (Pinus densiflora Sieb. et Zucc.). a) and b) marks will be used in 4.1 Increasing water deficits and leaf gas exchange.

$\sim 102 \%$ and $61 \% \sim 78 \%$ in $\mathrm{pF} 4.0$, respectively, in comparison to levels in $\mathrm{pF} 2.7$ (Table 3 ).

Under the same soil water conditions of $\mathrm{pF} 2.7$, the maximum daily $\mathrm{Ph}_{\mathrm{n}}$ and Tr were $6.834 \mu \mathrm{mol} \cdot \mathrm{m}^{-2}$. $\mathrm{s}^{-1}, 1.767 \mathrm{mmol} \cdot \mathrm{m}^{-2} \cdot \mathrm{s}^{-1}$, respectively, for Japanese cypress (Table 2) ; $12.971 \mu \mathrm{mol} \cdot \mathrm{m}^{-2} \cdot \mathrm{s}^{-1}, 4.488 \mathrm{mmol}$. $\mathrm{m}^{-2} \cdot \mathrm{s}^{-1}$, respectively, for Japanese red pine (Table 3). In pF 3.2 treatment, the maximum daily $\mathrm{Ph}_{\mathrm{n}}$ and Tr were $5.583 \mu \mathrm{mol} \cdot \mathrm{m}^{-2} \cdot \mathrm{s}^{-1}, 1.447 \mathrm{mmol} \cdot \mathrm{m}^{-2} \cdot \mathrm{s}^{-1}$, respectively, for Japanese cypress (Table 2); 11.079 $\mu \mathrm{mol} \cdot \mathrm{m}^{-2} \cdot \mathrm{s}^{-1}, 3.528 \mathrm{mmol} \cdot \mathrm{m}^{-2} \cdot \mathrm{s}^{-1}$, respectively, for Japanese red pine (Table 3). Japanese red pine had higher $\mathrm{Ph}_{\mathrm{n}}$ and $\mathrm{Tr}$ than Japanese cypress under the same soil water conditions.

WUE reached its peak twice a day (Fig. 4, Fig. 5) : in the morning and the afternoon in most measurements of both species. In the morning at fairly low leaf temperatures and ALVPD (Fig. 6), $\mathrm{Ph}_{\mathrm{n}}$ was intense and $\operatorname{Tr}$ was only moderate, yielding a high level of WUE. At midday, Tr increased 
Table 2 The maximum daily net photosynthesis $\left(\mathrm{Ph}_{\mathrm{n}}, \mu \mathrm{mol} \cdot \mathrm{m}^{-2} \cdot \mathrm{s}^{-1}\right)$ and transpiration $\left(\mathrm{Tr}, \mathrm{mmol} \cdot \mathrm{m}^{-2} \cdot \mathrm{s}^{-1}\right)$ for Japanese cypress.

\begin{tabular}{ccccccc}
\hline \multirow{2}{*}{ Month } & \multicolumn{2}{c}{$\mathrm{pF} 2.2$ treatment } & \multicolumn{2}{c}{$\mathrm{pF} 2.7$ treatment } & \multicolumn{2}{c}{$\mathrm{pF} 3.2$ treatment } \\
& $\mathrm{Ph}_{\mathrm{n}}$ & $\mathrm{Tr}$ & $\mathrm{Ph}_{\mathrm{n}}$ & $\mathrm{Tr}$ & $\mathrm{Ph}_{\mathrm{n}}$ & $\mathrm{Tr}$ \\
\hline May & 6.042 & 1.091 & $5.294(88)$ & $0.853(78)$ & $3.941(65)$ & $0.794(73)$ \\
Jun. & 7.885 & 1.514 & $6.547(83)$ & $0.938(62)$ & $4.346(55)$ & $0.578(38)$ \\
Jul. & 7.578 & 1.899 & $6.834(90)$ & $1.572(83)$ & $5.583(74)$ & $1.447(76)$ \\
Aug. & 7.813 & 1.716 & $6.537(84)$ & $1.153(67)$ & $4.394(56)$ & $1.072(62)$ \\
Sep. & 6.262 & 1.739 & $5.390(86)$ & $1.767(102)$ & $3.851(61)$ & $1.192(69)$ \\
Oct. & 5.822 & 1.196 & $5.396(93)$ & $0.911(76)$ & $5.498(94)$ & $0.886(74)$ \\
Nov. & 4.782 & 0.993 & $4.088(85)$ & $0.964(97)$ & $3.427(72)$ & $0.717(72)$ \\
\hline
\end{tabular}

Note: Numbers in parenthesis represent decreases of $\mathrm{Ph}_{\mathrm{n}}$ or $\mathrm{Tr}$ expressed as a percentage of maximum daily $\mathrm{Ph}_{\mathrm{n}}$ or $\operatorname{Tr}$ in $\mathrm{pF} 2.2$ respectively.

Table 3 The maximum daily net photosynthesis $\left(\mathrm{Ph}_{\mathrm{n}}, \mu \mathrm{mol} \cdot \mathrm{m}^{-2} \cdot \mathrm{s}^{-1}\right)$ and transpiration $\left(\operatorname{Tr}, \mathrm{mmol} \cdot \mathrm{m}^{-2} \cdot \mathrm{s}^{-1}\right)$ for Japanese red pine.

\begin{tabular}{cccrrrr}
\hline \multirow{2}{*}{ Month } & \multicolumn{2}{c}{$\mathrm{pF} 2.7$ treatment } & \multicolumn{2}{c}{$\mathrm{pF} 3.2$ treatment } & \multicolumn{2}{c}{$\mathrm{pF} 4.0$ treatment } \\
& $\mathrm{Ph}_{\mathrm{n}}$ & $\mathrm{Tr}$ & $\mathrm{Ph}_{\mathrm{n}}$ & $\mathrm{Tr}$ & $\operatorname{Ph}_{\mathrm{n}}$ & $\mathrm{Tr}$ \\
\hline Jul. & 6.783 & 1.647 & $5.275(78)$ & $1.791(109)$ & $5.492(81)$ & $1.220(74)$ \\
Aug. & 12.273 & 3.573 & $11.079(90)$ & $3.528(99)$ & $12.476(102)$ & $2.794(78)$ \\
Sep. & 10.031 & 4.488 & $9.450(94)$ & $3.284(73)$ & $9.219(92)$ & $2.717(61)$ \\
Oct. & 12.971 & 4.081 & $10.320(80)$ & $3.183(78)$ & $10.176(78)$ & $2.839(70)$ \\
Nov. & 12.190 & 3.591 & $8.698(71)$ & $2.578(72)$ & $8.581(70)$ & $2.476(69)$ \\
\hline
\end{tabular}

Note: Numbers in parenthesis represent decreases of $\mathrm{Ph}_{n}$ or Tr expressed as a percentage of maximum daily $\mathrm{Ph}_{\mathrm{n}}$ or $\operatorname{Tr}$ in $\mathrm{pF} 2.7$ respectively.
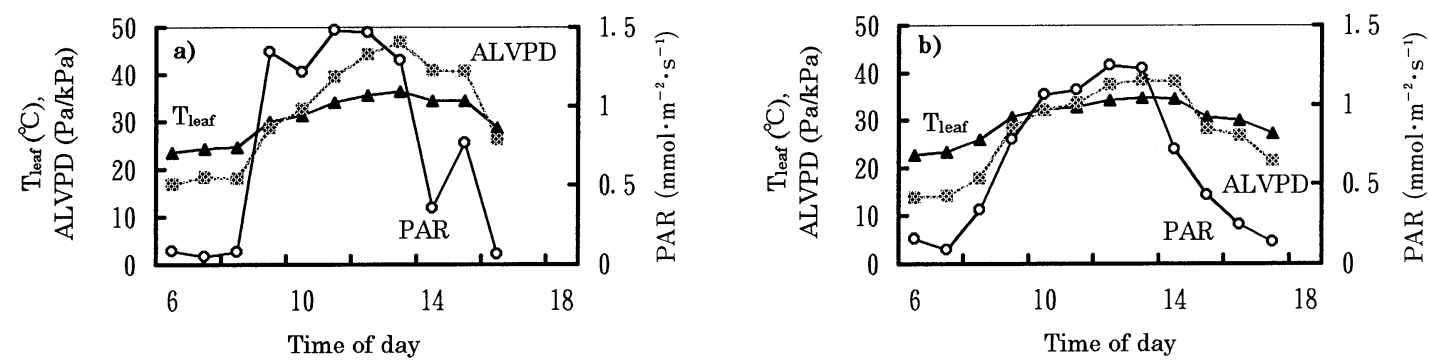

Fig. 6 Leaf microclimate conditions of photosynthetically active radiation (PAR), leaf temperature $\left(T_{1 e a f}\right)$ and air to leaf vapor pressure deficit (ALVPD) for a) Japanese cypress (Chamaecyparis obtusa Endl.) measured on Aug. 19 ; b) Japanese red pine (Pinus densiflora Sieb. et Zucc.) measured on Aug. 23, 1994.

Table 4 The daily average water use efficiency ( $\mu \mathrm{mol} / \mathrm{mmol}$ ) for Japanese cypress.

\begin{tabular}{cccc}
\hline Month & $\mathrm{pF} 2.2$ treatment & $\mathrm{pF} 2.7$ treatment & $\mathrm{pF} 3.2$ treatment \\
\hline May & $6.887 \pm 2.545$ & $8.861 \pm 3.271$ & $7.453 \pm 3.035$ \\
Jun. & $4.702 \pm 1.875$ & $4.672 \pm 2.908$ & $6.090 \pm 3.088$ \\
Jul. & $4.540 \pm 2.630$ & $5.283 \pm 2.673$ & $1.158 \pm 0.581^{*}$ \\
Aug. & $4.911 \pm 2.849$ & $6.500 \pm 4.260$ & $6.004 \pm 3.072$ \\
Sep. & $5.227 \pm 4.930$ & $4.608 \pm 4.063$ & $4.426 \pm 4.463$ \\
Oct. & $5.446 \pm 3.660$ & $5.457 \pm 2.280$ & $6.129 \pm 4.249$ \\
Nov. & $7.200 \pm 4.305$ & $6.304 \pm 4.470$ & $7.374 \pm 4.461$ \\
\hline
\end{tabular}

${ }^{*}$ Significant difference at $\mathrm{p} \leq 0.01$ by $t$ test. Data are the means and SDs. 
Table 5 The daily average water use efficiency $(\mu \mathrm{mol} / \mathrm{mmol})$ for Japanese red pine.

\begin{tabular}{cccc}
\hline Month & $\mathrm{pF} 2.7$ treatment & $\mathrm{pF} \mathrm{3.2} \mathrm{treatment}$ & $\mathrm{pF} \mathrm{4.0} \mathrm{treatment}$ \\
\hline Jul. & $4.549 \pm 1.659$ & $4.286 \pm 2.049$ & $4.166 \pm 1.669$ \\
Aug. & $4.772 \pm 1.250$ & $3.360 \pm 0.990$ & $4.132 \pm 1.850$ \\
Sep. & $1.913 \pm 1.007$ & $2.356 \pm 0.787$ & $2.018 \pm 1.335$ \\
Oct. & $3.495 \pm 2.204$ & $3.744 \pm 1.674$ & $3.796 \pm 1.578$ \\
Nov. & $3.270 \pm 1.136$ & $3.584 \pm 2.352$ & $3.840 \pm 1.305$ \\
\hline
\end{tabular}

${ }^{*}$ No significant difference at $\mathrm{p} \leq 0.05$ by $t$ test. Data are the means and SDs.

significantly while $\mathrm{Ph}_{n}$ remained at the same level or even dropped as a result of increasing respiration and water stress. Therefore the WUE was low. In the afternoon, $\mathrm{Tr}$ declined more rapidly than $\mathrm{Ph}_{\mathrm{n}}$ and recorded a high level of WUE. There was no significant differences in WUE between different treatments of each specimen for both species (Table 4, Table 5). Japanese cypress had relatively higher WUE than Japanese red pine under the same soil water conditions.

Japanese cypress and Japanese red pine had similar diurnal patterns of stomatal coductance to $\mathrm{CO}_{2}$ $\left(\mathrm{g}_{\mathrm{s}}\right.$ ) (Fig. 7). In most measurements, $\mathrm{g}_{\mathrm{s}}$ reached peaks in the morning, and recovered a little in the afternoon. $g_{s}$ decreased at lower soil water potential treatment for both species. Japanese red pine had higher $\mathrm{g}_{\mathrm{s}}$ than Japanese cypress under the same soil water conditions of $\mathrm{pF} 2.7$ and $\mathrm{pF} 3.2$ except the measurement in July, where difference in $g_{s}$ between two species was not significant as needles of Japanese red pine had just stopped expansion and not developed their full photosynthetic capacity (Table $6)$.

3.3 Seasonal fluctuation of daily amount of photosynthesis, transpiration and water use efficiency

In order to understand the difference of productivity of the two species, further more to find the best water condition to yield high productivity with the least water consumption, it is necessary to know the daily amount of $\mathrm{Ph}_{\mathrm{n}}$, Tr, and WUE.

We integrated daily $\mathrm{CO}_{2}$ uptake (IDCU) and $\mathrm{H}_{2} \mathrm{O}$ release (IDHR), and divided IDCU by IDHR to get daily WUE (Fig. 8).

IDCU of Japanese cypress peaked in July. IDHR had similar patterns of seasonal fluctuation to IDCU, but the shape was more convex than the IDCU. Therefore daily WUE was higher in early summer and late autumn than in mid-summer. IDCU of Japanese red pine showed two peaks with the low value in September caused by short period of cloud. IDHR of Japanese red pine peaked in August in $\mathrm{pF} 3.2$ and $\mathrm{pF} 4.0$ treatments, however, IDHR showed peak value in October in pF 2.7 treatment. Noticeable seasonal fluctuation in daily WUE was not present in Japanese red pine, the decrease in September could be for the same reason as mentioned above.

IDCU and IDHR of Japanese cypress decreased significantly in low soil water potential treatments in comparison with high soil water potential treatments. However, there was no significant difference in daily WUE between different treatments (Fig. 8, Table 7). IDCU of Japanese red pine in $\mathrm{pF} 3.2$ and $\mathrm{pF}$ 4.0 treatments were at the same level (Fig. 8, Table 7) and significantly lower than in $\mathrm{pF} 2.7$ treatment. IDHR of Japanese red pine in low soil water potential treatmemts decreased significantly in comparison to high soil water potential treatments. Daily WUE was not different among all three treatments (Fig. 8, Table 7).

Under the same soil water conditions of $\mathrm{pF} 2.7$, IDCU and IDHR of Japanese red pine were 1.8 and 2.9 times higher than that of Japanese cypress, respectively. Daily WUE was $36 \%$ lower in Japanese red pine than in Japanese cypress. A similar result was observed in $\mathrm{pF} 3.2$ (Table 7).

\section{Discussion}

4.1 Increasing water deficits and leaf gas exchange

Increased water deficits may alter leaf gas exchange in at least three ways. First, localized, transitory 
Japanese cypress
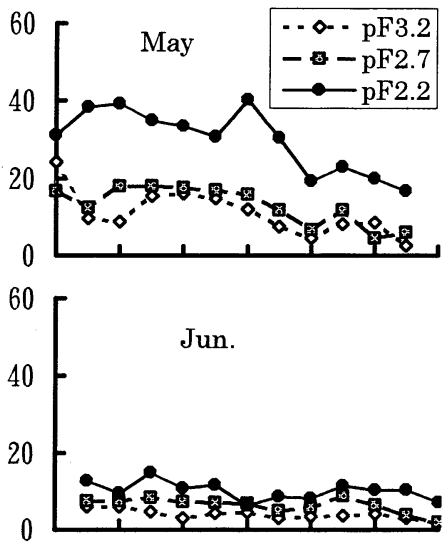

60

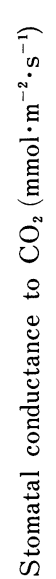

$40-\mathrm{Ju}$

20

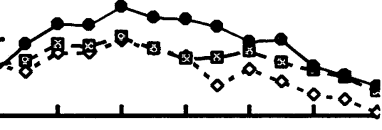

60

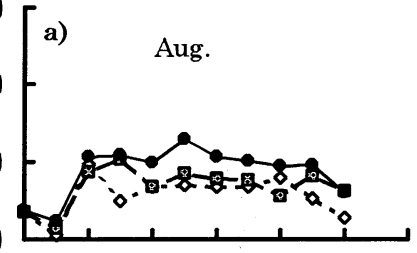

60
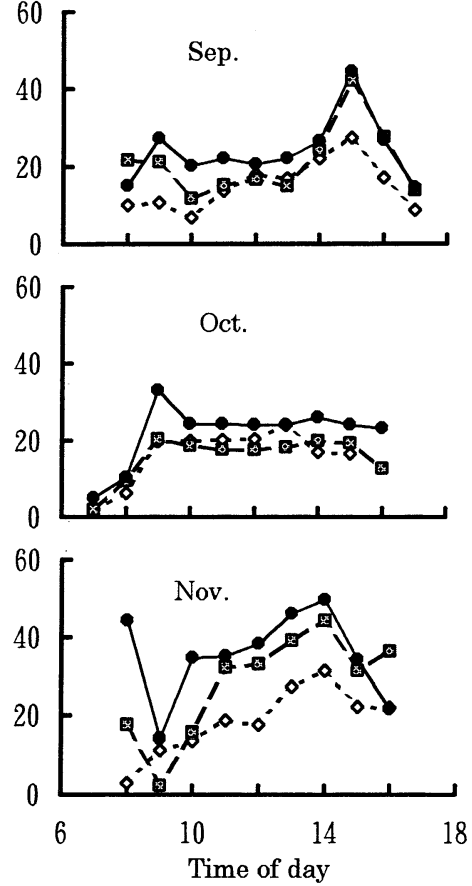

Fig. 7 The diurnal courses of stomatal conductance to $\mathrm{CO}_{2}$ for Japanese cypress (Chamaecyparis obtusa Endl.) and Japanese red pine (Pinus densiflora Sieb. et Zucc.). a) and b) marks will be used in 4.1 Increasing water deficits and leaf gas exchange.

Japanese red pine
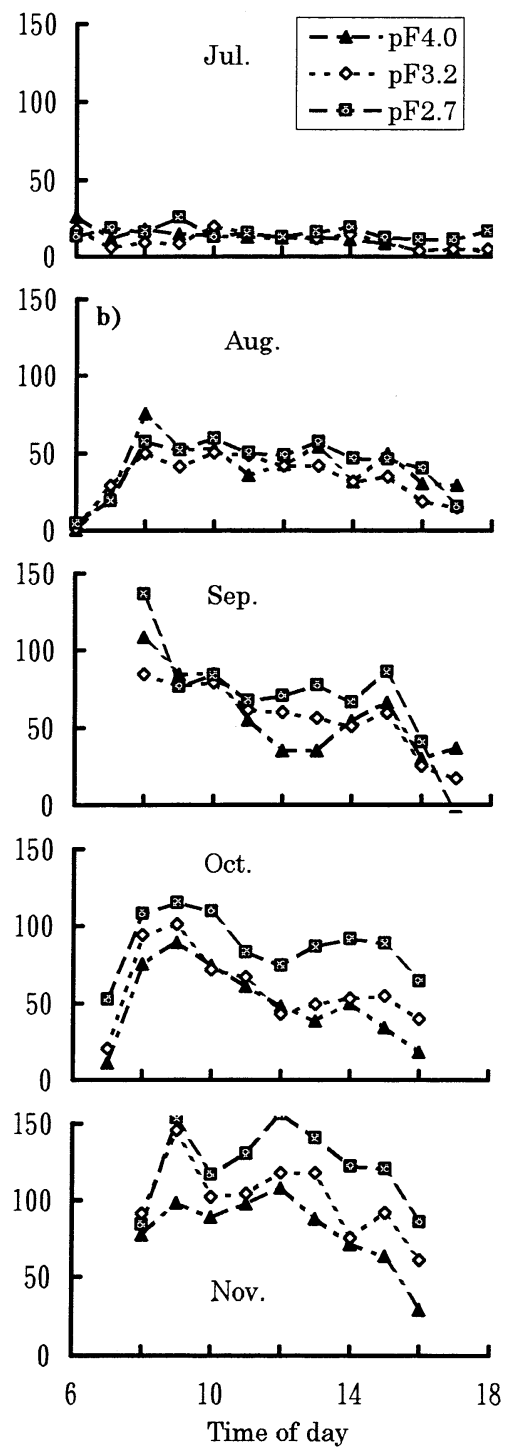
Table 6 Daily average stomatal conductance to $\mathrm{CO}_{2}\left(\mathrm{mmol} \cdot \mathrm{m}^{-2} \cdot \mathrm{s}^{-1}\right)$ for Japanese cypress and Japanese red pine.

\begin{tabular}{ccccc}
\hline \multirow{2}{*}{ Month } & \multicolumn{2}{c}{ pF 2.7 treatment } & \multicolumn{2}{c}{ pF 3.2 treatment } \\
& Japanese cypress & Japanese red pine & Japanese cypress & Japanese red pine \\
\hline Jul. & $14.800 \pm 3.826^{\mathrm{a}}$ & $15.592 \pm 3.993^{\mathrm{a}}$ & $11.615 \pm 5.752^{\mathrm{b}}$ & $10.715 \pm 5.116^{\mathrm{b}}$ \\
Aug. & $13.573 \pm 5.053$ & $41.475 \pm 18.171$ & $11.227 \pm 5.118$ & $52.458 \pm 24.286$ \\
Sep. & $20.980 \pm 9.011$ & $69.850 \pm 36.522$ & $15.744 \pm 6.553$ & $57.130 \pm 21.931$ \\
Oct. & $16.211 \pm 7.251$ & $59.430 \pm 24.855$ & $15.570 \pm 5.890$ & $87.510 \pm 20.145$ \\
Nov. & $28.000 \pm 13.391$ & $123.489 \pm 26.064$ & $18.600 \pm 8.517$ & $100.711 \pm 25.001$ \\
\hline
\end{tabular}

a,b No significant difference at $\mathrm{p} \leq 0.05$ by $t$ test. Data are the means and SDs.
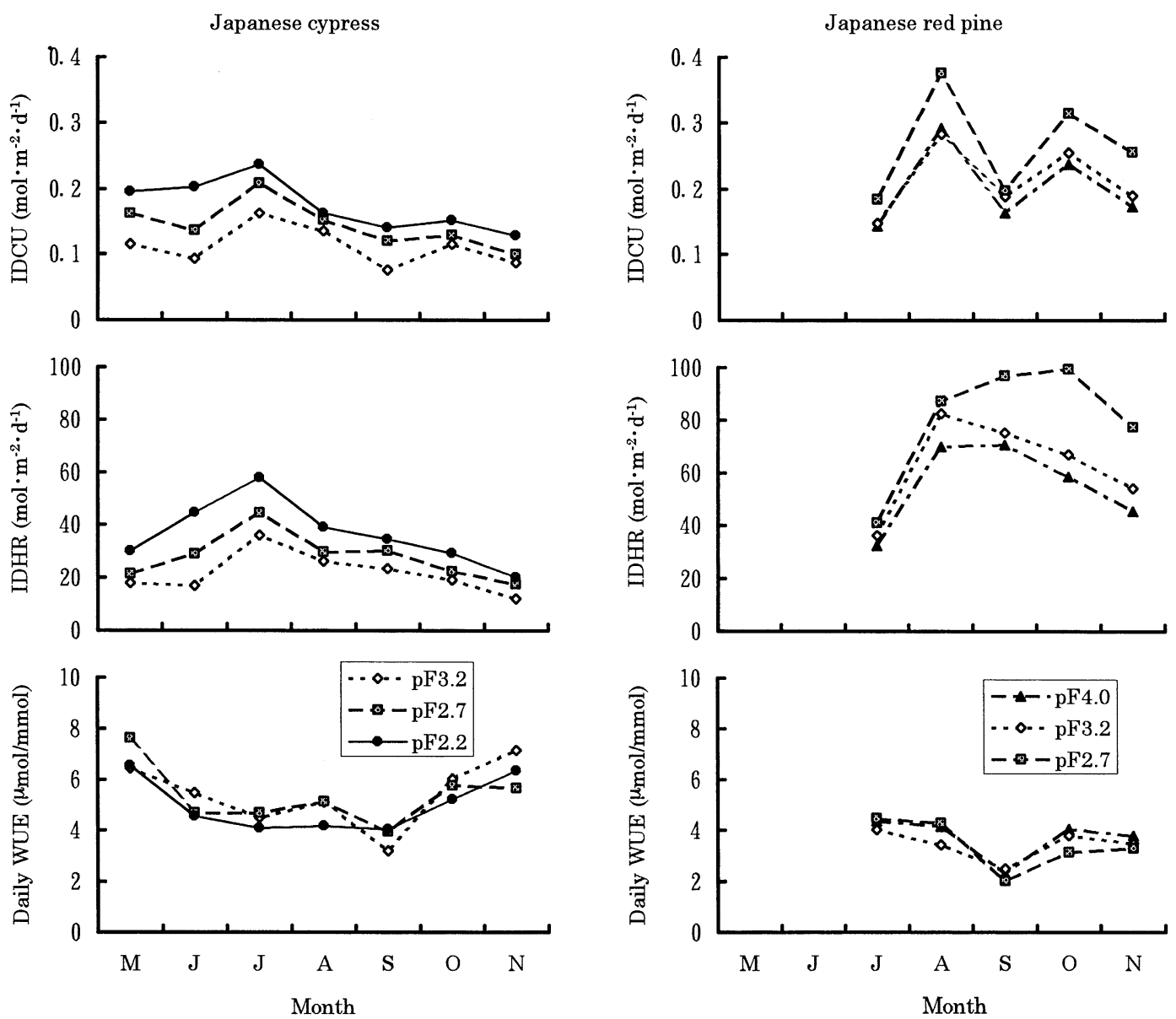

Fig. 8 The seasonal fluctuation of integrated daily $\mathrm{CO}_{2}$ uptake (IDCU), integrated daily $\mathrm{H}_{2} \mathrm{O}$ release (IDHR) and daily water use efficiency (daily WUE) for Japanese cypress (Chamaecyparis obtusa Endl.) and Japanese red pine (Pinus densiflora Sieb. et Zucc.). 
Table 7 Integrated daily $\mathrm{CO}_{2}$ uptake (IDCU, $\mathrm{mol} \cdot \mathrm{m}^{-2} \cdot \mathrm{d}^{-1}$ ), $\mathrm{H}_{2} \mathrm{O}$ release (IDHR, $\mathrm{mol} \cdot \mathrm{m}^{-2} \cdot \mathrm{d}^{-1}$ ) and daily water use efficiency (daily WUE) for Japanese cypress and Japanese red pine.

\begin{tabular}{llcccc}
\hline & & $\mathrm{pF} 2.2$ & $\mathrm{pF} 2.7$ & $\mathrm{pF} 3.2$ & $\mathrm{pF} 4.0$ \\
\hline \multirow{3}{*}{ Japanese cypress } & IDCU & $0.174 \pm 0.036$ & $0.144 \pm 0.033$ & $0.112 \pm 0.028$ & \\
& IDHR & $36.471 \pm 11.340$ & $27.851 \pm 8.131$ & $21.667 \pm 7.223$ & \\
& Daily WUE & $4.986 \pm 0.987^{\mathrm{a}}$ & $5.358 \pm 1.089^{\mathrm{a}}$ & $5.416 \pm 1.203^{\mathrm{a}}$ & \\
\hline \multirow{3}{*}{ Japanese red pine } & IDCU & & $0.265 \pm 0.072$ & $0.212 \pm 0.049^{\mathrm{b}}$ & $0.202 \pm 0.055^{\mathrm{b}}$ \\
& IDHR & & $80.520 \pm 21.172$ & $63.032 \pm 16.348$ & $55.570 \pm 14.714$ \\
& Daily WUE & & $3.453 \pm 0.882^{\mathrm{c}}$ & $3.456 \pm 0.525^{\mathrm{c}}$ & $3.743 \pm 0.743^{\mathrm{c}}$ \\
\hline
\end{tabular}

a,b,c No significant difference at $\mathrm{p} \leq 0.05$ by $t$ test. Data are the means and SDs from May to Nov., for Japanese cypress; from Jul. to Nov., for Japanese red pine.

water stress that developed during periods of high transpiration reduced assimilation rate (SHARKEY, 1984 ; NowAK et al., 1988). Second, the longer-term development of water deficits over a period of days or weeks gradually decreased the magnitude of both stomatal conductance and assimilation in a number of species (BAtes and HAll, 1982 ; Ehleringer and CoOK, 1984 ; Gollan et al., 1985 ; TuRner et al., 1985 ; NowAK et al., 1988). Finally, the functional relationships between gas exchange and environmental parameters can be altered (BATES and HALl, 1982 ; Gollan et al., 1985 ; TURNER et al., 1985), although this effect has not been a universal response of plants to water stress (SCHUlZE and KÜPPERS, 1979).

For Japanese red pine and Japanese cypress, both the transitory and long-term development of water deficits generally reduced the magnitude of gas exchange. Evidence that high transpiration rates reduced assimilation was present on August 19 (Fig. 4a, Fig. 4b, Fig. 7a), for Japanese cypress ; on August 23 (Fig. 5a, Fig. 5b, Fig. 7b), for Japanese red pine: after 10 o'clock, stomatal conductance was relatively constant, transpiration increased greatly, and assimilation rates decreased. During long-term development of drought stress, the magnitude of stomatal conductance and assimilation decreased. The evidence came from the diurnal courses of photosynthesis and stomatal conductance under different soil water conditions, for Japanese cypress (Fig. 4, Fig.7) and Japanese red pine (Fig. 5, Fig. 7). Finally, the functional relationships between gas exchange and environmental parameters such as temperature, vapor gradient should be further studied under steady environmental conditions.

4. 2 The optimum soil water condition

Japanese cypress and Japanese red pine decreased photosynthesis at lower soil water potential conditions (Fig. 4, Fig. 5). This is partially caused by stomatal limitation (Fig. 7). Transpiration was also limited at the same time (Fig. 4, Fig. 5). However, no distinct difference in water use efficiency was observed under different soil water potential conditions based on diurnal courses of WUE (Fig. 4, Fig. 5, Table 4, Table 5) and daily WUE data (Fig. 8, Table 7).

Under the same soil water conditions, Japanese red pine had higher $\mathrm{Ph}_{\mathrm{n}}$ than Japanese cypress (Table 2 , table 3) as well as IDCU (Table 7). This indicates that the productivity of Japanese red pine is higher than that of Japanese cypress, although the daily WUE of Japanese cypress was higher than that of Japanese red pine (Fig. 8).

Based on our measurements, Japanese cypress is a suitable tree species for afforestation in $\mathrm{pF} 2.7$ or $\mathrm{pF}$ 3.2 soil, and Japanese red pine is suitable in $\mathrm{pF} 3.2$ or even in $\mathrm{pF} 4.0$ soil.

\section{Acknowledgments}

The authors would like to thank the students of the silvicultural laboratory who helped to do the transplantation work and measurement assistance. They also thank Michael E. Jackson of the same laboratory for his English correction. 


\section{References}

BATES L.M. and HALL A.E. : Diurnal and seasonal responses of stomatal conductance for cowpea plants subjected to different levels of environmental drought, Oecologia 54, 304-308, 1982

EHLERINGER J.R. and COOK C.S.: Photosynthesis in Encelia farinosa Gray in response to decreasing leaf water potential, Plant Physiol. 75, 688-693, 1984

HATTORI S., TAMAI K. and ABE T.: Effects of soil moisture and vapor pressure deficit on evapotranspiration in a hinoki plantation, J. Jpn. For. Soc. 75, 216-224, 1993 (only in Japanese with English summary)

FARQUHAR G.D. and SHARKey T.D. : Stomatal conductance and photosynthesis, Ann. Rev. Plant Physiol. 33,317 $-345,1982$

GOLlAN T., TURNER N.C. and SCHUlzE E.-D. : The responses of stomata and leaf gas exchange to vapor pressure deficits and soil water content. III. In the sclerophyllous woody species Nerium oleander, Oecologia 65, 356 $-362,1985$

LAnGE O.L., Kilian E., Meyer A. and Tenhunen J.D. : Measurement of lichen photosynthesis in the field with a portable steady-state $\mathrm{CO}_{2}$-porometer, Lichenologist $\mathbf{1 6}, 1-9,1984$

LARCHER W. : The influence of water stress on the relationship between $\mathrm{CO}_{2}$ uptake and transpiration. In Water stress in plants, edited by BoHDAN SLAVÍK, Dr. W. JUNK publishers, the Hague., pp. 184-193, 1965

NEGISI, K.: Photosynthesis, respiration, and growth in 1-year-old seedlings of Pinus densiflora, Cryptomeria japonica, and Chamaecyparis obtusa, Bull. Tokyo Univ. For. 62, 1-115, 1966

NOWAK R.S., ANDERSON J.E. and TOFT N.L.: Gas exchange of Agropyron desertorum : diurnal patterns and responses to water vapor gradient and temperature, Oecologia 77, 289-295, 1988

SATOO, T. : Drought resistance of some conifers at the first summer after their emergence, Bull. Tokyo Univ. For. 51, 1-108, 1956 (only in Japanese with English summary)

SHARKEY T.D. : Transpiration-induced changes in the photosynthetic capacity of leaves, Planta 160, 143-150, 1984

SCHUlzE E.-D.: Carbon dioxide and water vapor exchange in response to drought in the atmosphere and in the soil, Ann. Rev. Plant Physiol. 37, 247-274, 1986

SCHUlzE E.-D. and HALL A.E. : Stomatal responses, water loss and $\mathrm{CO}_{2}$ assimilation rates of plants in contrasting environments. In Physiological plant ecology II : water relations and carbon assimilation, Encyclopedia of plant physiology, New series vol.12B, edited by LANGE O.L., NOBEL P.S., OSMOND C.B. and ZIEGLER H., Springer-Verlag, New York, pp. 747, 1982

SCHUlzE E.-D., HALl A.E., LANGE O.L. and WALZ H. : A portable steady-state porometer for measuring the carbon dioxide and water vapour exchanges of leaves under natural conditions, Oecologia (Berl) 53, 141-145, 1982

SCHUlZE E.-D. and KÜPPERS M. : Short-term and long-term effects of plant water deficits on stomatal response to humidity in Corylus avellana L., Planta 146, 319-326, 1979

TURNER N.C., SCHUlzE E.-D. and Gollan T. : The response of stomata and leaf gas exchange to vapour pressure deficits and soil water content. II. In the mesophytic herbaceous species Helianthus annuuns, Oecologia 65, 348-355, 1985

WAYNE P.M. and BAZZAZ F.A. : Birch seedling responses to daily courses of light in experimental forest gaps and shadehouses, Ecology 74, 1500-1515, 1993

(Received October 30, 1995)

\section{要旨}

5 月から11月までヒノキ (Chamaecyparis obtusa Endl.) とアカマツ (Pinus densiflora Sieb. et Zucc.) の 3 年生苗木の光合成・蒸散速度の日変化及び季節変化を測定した。潅水量によって, 土壤水分を 3 段階に設定 した。両樹種ともに, 午前中に純光合成速度がピークになったが, その時間は蒸散のほうが光合成より遅かっ た。土壌含水比が低い場合は, 純光合成速度, 蒸散速度及び気孔コンダクタンスが減少したが, 水利用効率に 違いは見られなかった。ヒノキの総同化量は 7 月にピークになったが,アアカマツの場合は，8月にピークにな った。アカマツの $\mathrm{pF} 2.7$ 処理区では, 総蒸散量は10月に最も多かったが, それ以外の処理区では総同化量と 同じような季節変化を示した。ヒノキの水利用効率は $5,10,11$ 月に高く，6月から 9 月まで低かった。一方， 
アカマツの水利用効率は季節を通して変化しなかった。土壤含水比が低い場合は, 総同化量および総蒸散量が 減ったが，水利用効率に違いが見られなかった。ヒノキとアカマツの純光合成速度を同じ土壌水分条件で比べ ると,アカマツのほうがヒノキより優れていたので,アカマツはヒノキより耐乾性が優れていると思われる。 